\title{
Effect of Diazotrophs and Chemical Fertilizers on Production and Economics of Okra (Abelmoschus esculentus, L.) Cultivars
}

\author{
Barnali Mal $^{1}$, Premananda Mahapatra ${ }^{1}$, Santanu Mohanty ${ }^{2}$ \\ ${ }^{1}$ Department of Vegetable Science, College of Agriculture, Orissa University of Agriculture and Technology, Bhubaneswar, India; \\ ${ }^{2}$ Department of Soil Science and Agricultural Chemistry, Orissa University of Agriculture and Technology, Bhubaneswar, India. \\ Email: barnalimal@yahoo.com
}

Received November $12^{\text {th }}, 2013$; revised December $13^{\text {th }}, 2013$; accepted January $9^{\text {th }}, 2014$

Copyright (C) 2014 Barnali Mal et al. This is an open access article distributed under the Creative Commons Attribution License, which permits unrestricted use, distribution, and reproduction in any medium, provided the original work is properly cited. In accordance of the Creative Commons Attribution License all Copyrights (C) 2014 are reserved for SCIRP and the owner of the intellectual property Barnali Mal et al. All Copyright @ 2014 are guarded by law and by SCIRP as a guardian.

\section{ABSTRACT}

The effect of diazotrophs and chemical fertilizers on yield attributing characters and economics of okra cultivation was evaluated. Application of highest dose of NPK @100\% in combination with vermicompost $\left(5 \mathrm{t} \mathrm{ha}^{-1}\right)$ and biofertilizers with FYM increased the fruit yield of okra (cultivar Mahyco-10) considerably with yield varying between $80.00 \mathrm{q} \mathrm{ha}^{-1}$ to $227.13 \mathrm{q} \mathrm{ha}^{-1}$ and $80.49 \mathrm{q} \mathrm{ha}^{-1}$ to $229.62 \mathrm{q} \mathrm{ha}^{-1}$ during 2010 and 2011 respectively. In okra cv. Utkal Gaurav the fruit yield varied from $47.68 \mathrm{q} \mathrm{ha}^{-1}$ to $129.84 \mathrm{q} \mathrm{ha}^{-1}$ in 2010 and $47.27 \mathrm{q} \mathrm{ha}^{-1}$ to 131.35 $\mathrm{q} \mathrm{ha}^{-1}$ in 2011. As regards the net return, highest net profit of Rs 87,630 and Rs. 89,370 $\mathrm{ha}^{-1}$ from the okra was realized over an investment of Rs. 71,360 ha ${ }^{-1}$ during both the years with a benefit cost ratio of 2.23 and 2.25 when $100 \%$ NPK integrated with vermicompost @5t ha ${ }^{-1}$ and biofertilizers with FYM applied in okra cv.Mahyco-10. The highest net return of Rs. 14,350 in 2010 and Rs. 15,260 in 2011 with an investment of Rs. 63,550 each year was found in cultivar Utkal Gaurav under highest level of nutrient application.

\section{KEYWORDS}

\section{Bio-Fertilizers; Vermicompost; Diazotrophs; Okra}

\section{Introduction}

Okra (Abelmoschus esculentus, L.) originated from tropical and subtropical Africa and is natural to West Africa [1]. India is considered as the secondary centre of diversity. In India, okra covers an area of 349.4 thousand hectares with production of 3.66 million tons [2]. Injudicious and indiscriminate application of chemical fertilizers has created serious damages to the soil health, environment and is threatening the health of millions of people throughout the world and more importantly declining the productivity of soil. Sustainable increase in production is possible by adopting integrated fertilizer management which necessitates the use of vermicompost and biofertilizers.

The vegetable production in India is still dominated by locally available genotypes. Therefore, there is a need to use hybrids as well as open pollinated high yielding va- rieties for enhancing the productivity and at the same time it is highly essential to maintain soil fertility and adopt environment friendly scientific management of chemical fertilizers and organic resources. Thus there is a great scope to replace locally available genotypes with hybrids and open pollinated high yielding varieties with tolerance/resistance to important pest and diseases [3]. Scientific packages on the integrated use of vermicompost and biofertilizers along with chemical fertilizers for successful cultivation of hybrids and open pollinated high yielding varieties is lacking. The present research work was taken up with a view to evaluating the effect of integrated use of diazotrophs and chemical fertilizers on production and economics of okra cultivation.

\section{Materials and Methods}

Field experiments were undertaken during the summer 
seasons of 2010 and 2011 in the Experimental Research farm of Orissa University of Agriculture and Technology (OUAT), Bhubaneswar, India. Experiments were conducted to evaluate the performances of two okra varieties viz., F1 hybrid and open pollinated high yielding variety under different nutrient management practices to recommend the best suited management package. Bhubaneswar is located in the tropical climate zone at a latitude of $22^{\circ} 15^{\prime} \mathrm{N}$, longitude of $80^{\circ} 22^{\prime} \mathrm{E}$ and on an altitude of $25.5 \mathrm{~m}$ above the mean sea level (MSL). The place is characterized by warm and moist climate with hot and humid summer and mild winter. Seeds of both okra cv. Mahyco-10 (V1) and Utkal Gaurav (V2) were planted on February 15, 2010 and February 17, 2011 in the experimental field. Plot sizes of $3 \mathrm{~m} \times 3 \mathrm{~m}$ were laid out in Randomized Block Design (RBD) with three replications. Altogether nine fertilizer treatments including control were used for each variety. The detailed treatments of the experiment is shown in Table 1.

\subsection{Evaluation of Performance Parameters}

\subsubsection{Yield and Yield Attributing Characteristics}

1) Number of fruits per plant: Numbers of marketable tender fruits produced from ten randomly selected plants of each treatment and replication were recorded and the mean value was finally used for further analysis.

2) Single fruit weight: Mean weight of ten randomly selected fruits of each treatment and replication were recorded, tabulated and expressed in gram (g).

3) Fruit yield: Weight of total quantity of harvested fruits per plant for each treatment and replication was measured and the yield per hectare was calculated and expressed in $\mathrm{q} \mathrm{ha}^{-1}$.

\subsubsection{Economics of Okra Cultivation}

Cost of cultivation was calculated on the basis of prevailing market prices and inputs used in cultivation of okra. The produce obtained from different treatments was converted into gross return (Rs. ha ${ }^{-1}$ ) by multiplying the produce with the whole sale market price. Net return from the produce was calculated by deducting the cost of cultivation from the gross return. The benefit cost ratio, which implies the return per rupee invested, was worked out for different treatments by dividing the gross return with the corresponding cost of cultivation.

\section{Results and Discussion}

\subsection{Number of Fruits per Plant}

The numbers of fruits per plant for both the varieties for 2010 are presented in Table 2. There was significant variation in the number of fruits per plant in both the varieties. During 2010 the highest numbers (18.70) of fruits per plant in Mahyco-10 were recorded in $\mathrm{V}_{1} \mathrm{~T}_{6}$ followed by $\mathrm{V}_{1} \mathrm{~T}_{8}$ (18.35), $\mathrm{V}_{1} \mathrm{~T}_{7}$ (18.28) and $\mathrm{V}_{1} \mathrm{~T}_{9}$ (17.88). The lowest numbers of fruits (10.26) were in the control $\mathrm{V}_{1} \mathrm{~T}_{1}$ where only FYM @10 t ha1 was applied. In case of okra cv. Utkal Gaurav, the maximum and the minimum numbers of fruits per plant (14.71) and (9.52) were observed in $\mathrm{V}_{2} \mathrm{~T}_{3}$ and $\mathrm{V}_{2} \mathrm{~T}_{1}$ respectively in 2010. However in 2011 the highest number of fruits (18.84) was recorded in $\mathrm{V}_{1} \mathrm{~T}_{9}$ followed by $\mathrm{V}_{1} \mathrm{~T}_{6}$ (17.96) $\mathrm{V}_{1} \mathrm{~T}_{7}$ (17.31) and $\mathrm{V}_{1} \mathrm{~T}_{8}$ (17.15) in Mahyco-10 (Table 3). The lowest numbers of fruits (10.52) were in the control $\mathrm{V}_{1} \mathrm{~T}_{1}$. The highest (14.82) and the lowest (10.63) numbers of fruits in Utkal Gaurav were found in $\mathrm{V}_{2} \mathrm{~T}_{3}$ and $\mathrm{V}_{2} \mathrm{~T}_{1}$ respectively.

In the present investigation, different treatments significantly increased the number of fruits per plant over the control. This might be due to sole or integrated application of FYM $\left(10 \mathrm{tha}^{-1}\right)$, chemical fertilizers $(100 \%$ RDF or $75 \%$ RDF) along with vermicompost ( $5 \mathrm{tha}^{-1}$ or $2.5 \mathrm{t} \mathrm{ha}^{-1}$ ) and biofertilizers which increased the availability and uptake of nutrients for a longer duration. Both vermicompost and biofertilizer might have been involved in the various endogenous hormonal functions in the plant tissues which might be responsible for enhanced pollen germination and pollen tube growth and ultimately increased the fruit set as well as increased numbers of fruits per plant. Similar findings of significantly higher number of fruits per plant by integrated application of chemical fertilizer, organic manures and biofertilizers were reported by Prabhu et al. [4] in okra. Among the treatments, application of $100 \%$ RDF or $75 \%$ RDF + vermicompost @5 t ha ${ }^{-1}$ or 2.5 t ha $^{-1}+$ biofertilizer proved to be the best treatment for both F1 hybrid Mahyco-10 as well as high yielding open pollinated Utkal Gaurav varieties of okra. The maximum number of fruits per plant was reported by Neeraja et al. [5] in okra due to application of organic nutrients which resulted in better vegetative growth with higher number of fruits per plant. Fatokun and Chheda [6] also observed that the increase in fruit yield was primarily due to an increase in the number of fruits per plant when the highest levels of phosphorus and nitrogen were applied.

\subsection{Single Fruit Weight}

From the data presented in Table 2, it can be clearly observed that during 2010, the highest individual fruit weight $(18.22 \mathrm{~g})$ for Mahyco-10 was recorded in $\mathrm{V}_{1} \mathrm{~T}_{6}$ which was significantly superior to the rest of the treatments. This was followed by $V_{1} T_{9}(17.86 \mathrm{~g})$ and $\mathrm{V}_{1} \mathrm{~T}_{8}(17.24 \mathrm{~g})$. The lowest value (11.75 g) in the same year was recorded in $V_{1} T_{1}$. It is also seen from the table that for cv. Utkal Gaurav, the highest individual fruit weight (15.15 g) was in $\mathrm{V}_{2} \mathrm{~T}_{6}$ followed by $\mathrm{V}_{2} \mathrm{~T}_{8}(13.25 \mathrm{~g})$ in the first year while the lowest 
Table 1. Detail of experimental treatments (variety: mahyco-10 and utkal gaurav).

\begin{tabular}{|c|c|}
\hline Notations & Treatments \\
\hline $\mathrm{T}_{1}$ & Control (FYM@10 t ha ${ }^{-1}$ ) \\
\hline $\mathrm{T}_{2}$ & FYM $\left(10 \mathrm{t} \mathrm{ha}^{-1}\right)+100 \%$ RDF (NPK) \\
\hline $\mathrm{T}_{3}$ & FYM $\left(10 \mathrm{t} \mathrm{ha}^{-1}\right)+75 \%$ RDF (NPK) \\
\hline $\mathrm{T}_{4}$ & FYM $\left(10 \mathrm{t} \mathrm{ha}^{-1}\right)+100$ \% RDF (NPK) + Bio-fertilizer (Azotobactor, Azospirillum and PSB (1:1:1) @12 kg ha ${ }^{-1}$ ) \\
\hline $\mathrm{T}_{5}$ & FYM $\left(10\right.$ t ha $\left.^{-1}\right)+75$ \% RDF (NPK) + Bio-fertilizer(Azotobactor, Azospirillum and PSB (1:1:1) @12 kg ha-1) \\
\hline $\mathrm{T}_{6}$ & FYM $\left(10 \mathrm{t} \mathrm{ha}^{-1}\right)+100 \%$ RDF (NPK)+ Vermicompost $\left(5 \mathrm{t} \mathrm{ha}^{-1}\right)+$ Bio-fertilizer (Azotobactor, Azospirillum and PSB (1:1:1)@12 kg ha-1) \\
\hline $\mathrm{T}_{7}$ & FYM $\left(10 \mathrm{t} \mathrm{ha}^{-1}\right)+75 \%$ RDF (NPK) + Vermicompost $\left(2.5 \mathrm{t} \mathrm{ha}^{-1}\right)+$ Biofertilizer (Azotobactor, Azospirillum and PSB (1:1:1) @12 kg ha $\left.{ }^{-1}\right)$ \\
\hline $\mathrm{T}_{8}$ & FYM $\left(10\right.$ t ha $\left.^{-1}\right)+100 \%$ RDF (NPK) + Vermicompost $\left(2.5\right.$ t ha-1 $^{-1}+$ Biofertilizer (Azotobactor, Azospirillum and PSB (1:1:1) @12 kg ha $\left.{ }^{-1}\right)$ \\
\hline $\mathrm{T}_{9}$ & FYM $\left(10 \mathrm{t} \mathrm{ha}^{-1}\right)+75 \%$ RDF (NPK) + Vermicompost $\left(5 \mathrm{t} \mathrm{ha}^{-1}\right)+$ Biofertilizer (Azotobactor, Azospirillum and PSB (1:1:1) @12 kg ha $\left.{ }^{-1}\right)$ \\
\hline
\end{tabular}

Diazotrophs: Nitrogen fixing bacteria; FYM: Farm yard manure; PSB: Phosphate solubilizing bacteria; NPK: Nitrogen, Phosphorus and Potassium; RDF: Recommended dose of fertilizer, NPK kg ha ${ }^{-1}$ (Mahyco-10: 200:100:100, Utkal Gaurav: 110:75:75).

Table 2. Fruit yield and yield attributing characters of okra influenced by diazotrophs and chemical fertilizers.

\begin{tabular}{|c|c|c|c|c|c|c|}
\hline \multirow{2}{*}{$\begin{array}{l}2010 \\
\text { Treatments }\end{array}$} & \multicolumn{3}{|c|}{ Mahyco-10 } & \multicolumn{3}{|c|}{ Utkal Gaurav } \\
\hline & $\begin{array}{l}\text { Number } \\
\text { of fruits }\end{array}$ & $\begin{array}{c}\text { Single fruit } \\
\text { weight (g) }\end{array}$ & $\begin{array}{c}\text { Total fruit } \\
\text { yield }\left(\mathbf{q} \text { ha }^{-1}\right)\end{array}$ & $\begin{array}{l}\text { Number } \\
\text { of fruits }\end{array}$ & $\begin{array}{l}\text { Single fruit } \\
\text { weight (g) }\end{array}$ & $\begin{array}{l}\text { Total fruit } \\
\text { yield }\left(\mathrm{q} \mathrm{ha} \mathbf{a}^{-1}\right)\end{array}$ \\
\hline $\mathrm{T}_{1}$ & 10.26 & 11.75 & 80.00 & 9.52 & 7.51 & 47.68 \\
\hline $\mathrm{T}_{2}$ & 17.34 & 14.83 & 171.37 & 13.88 & 9.89 & 91.53 \\
\hline $\mathrm{T}_{3}$ & 17.59 & 14.24 & 167.00 & 14.71 & 9.20 & 90.23 \\
\hline $\mathrm{T}_{4}$ & 17.22 & 15.86 & 182.06 & 12.56 & 11.00 & 92.03 \\
\hline $\mathrm{T}_{5}$ & 17.60 & 15.22 & 178.63 & 13.25 & 10.36 & 91.55 \\
\hline $\mathrm{T}_{6}$ & 18.70 & 18.22 & 227.13 & 12.87 & 15.15 & 129.84 \\
\hline $\mathrm{T}_{7}$ & 18.28 & 16.56 & 201.75 & 12.99 & 12.13 & 105.03 \\
\hline $\mathrm{T}_{8}$ & 18.35 & 17.24 & 210.84 & 12.53 & 13.25 & 110.65 \\
\hline $\mathrm{T}_{9}$ & 17.88 & 17.86 & 212.82 & 13.79 & 12.95 & 118.94 \\
\hline SEM & 0.20 & 0.19 & 1.24 & 0.17 & 0.18 & 0.24 \\
\hline $\mathrm{CD}_{(0.05)}$ & 0.60 & 0.56 & 3.72 & 0.52 & 0.52 & 0.73 \\
\hline
\end{tabular}

fruit weight $(7.51 \mathrm{~g})$ recorded was in $\mathrm{V}_{2} \mathrm{~T}_{1}$.

However, in the second year of experiment it could be observed (Table 3) that for Mahyco-10 the highest value (19.18 g) was recorded in $\mathrm{V}_{1} \mathrm{~T}_{6}$ which was significantly superior to rest of the treatments followed by $\mathrm{V}_{1} \mathrm{~T}_{8}(18.52 \mathrm{~g})$, $\mathrm{V}_{1} \mathrm{~T}_{7}(17.82 \mathrm{~g})$ and $\mathrm{V}_{1} \mathrm{~T}_{9}$ (17.09 g). The lowest individual fruit weight (11.48 g) was found in $V_{1} T_{1}$. In the second year the highest value (15.49 $\mathrm{g}$ ) for variety $\mathrm{V}_{2}$ was recorded in $\mathrm{V}_{2} \mathrm{~T}_{6}$ which was significantly superior as compared to rest of the treatments followed by $\mathrm{V}_{2} \mathrm{~T}_{8}(14.80$ g). The minimum fruit weight was recorded in the control $\mathrm{V}_{2} \mathrm{~T}_{1}(6.67 \mathrm{~g})$ which was significantly inferior to rest of the treatments.

Single fruit weight is the direct and positive contributory factor to yield per plant in okra. The better efficacy of the combined use of fertilizer sources over both sole application of inorganic fertilizers and the control might be due to availability and uptake of more plant nutrients resulting in luxuriant vegetative growth with more leaf area. This increased photosynthetic area and translocation of photosynthates in plants, subsequently accelerated the formation of more number of large sized fruits with more number of seeds per fruits resulting in increase in fruit weight. Similar results for okra were also reported by Pandey et al. [7] Naik and Srinivas [8] and Ahmed and Tanki [9].

The favorable C: $\mathrm{N}$ ratio and appreciably higher contents of all the macro and micro nutrients and their ready availability for a longer period due to slow releases could be the possible reasons for spectacular influence on the fruit weight in okra. Similarly, the better efficacy of vermicompost @ 2.5 t ha-1 along with 50\% RDF and seed inoculation, as evident in the studies, might be due to accumulation of mobile substances in earthworm casts $[10,11]$, and increase in available $\mathrm{N}$ and $\mathrm{P}$ in okra [12]. Birbal et al. [13] found that application of nitrogen at the rate of $100 \mathrm{~kg}$ ha-1 significantly improved the weight of individual fruit over control. Increasing levels of K (maximum @100 kg ha-1) significantly increased the single fruit weight in okra [14].

\subsection{Yield}

The highest yields (227.13 $\mathrm{q} \mathrm{ha}^{-1}$ ) in Mahyco-10 and 
Table 3. Fruit yield and yield attributing characters of okra influenced by diazotrophs and chemical fertilizers.

\begin{tabular}{ccccccc}
\hline \multirow{2}{*}{ Treatments } & \multicolumn{3}{c}{ Mahyco-10 } & & \multicolumn{2}{c}{ Utkal Gaurav } \\
\cline { 2 - 7 } & $\begin{array}{c}\text { Number of } \\
\text { fruits }\end{array}$ & $\begin{array}{c}\text { Single fruit/ } \\
\text { weight (g) }\end{array}$ & $\begin{array}{c}\text { Total fruit } \\
\left.\text { yield (q ha } \mathbf{- 1}^{-1}\right)\end{array}$ & $\begin{array}{c}\text { Number } \\
\text { of fruits }\end{array}$ & $\begin{array}{c}\text { Single fruit } \\
\text { weight (g) }\end{array}$ & $\begin{array}{c}\text { Total fruit } \\
\text { yield (q ha-1) }\end{array}$ \\
\hline $\mathrm{T}_{1}$ & 10.52 & 11.48 & 80.49 & 10.63 & 6.67 & 47.27 \\
$\mathrm{~T}_{2}$ & 16.55 & 15.83 & 174.54 & 14.11 & 9.84 & 92.55 \\
$\mathrm{~T}_{3}$ & 16.74 & 15.26 & 170.28 & 14.82 & 9.16 & 90.43 \\
$\mathrm{~T}_{4}$ & 17.05 & 16.29 & 185.10 & 11.94 & 11.87 & 94.45 \\
$\mathrm{~T}_{5}$ & 16.11 & 16.83 & 180.77 & 12.64 & 11.10 & 93.56 \\
$\mathrm{~T}_{6}$ & 17.96 & 19.18 & 229.62 & 12.72 & 15.49 & 131.35 \\
$\mathrm{~T}_{7}$ & 17.31 & 17.82 & 205.60 & 12.36 & 13.22 & 108.81 \\
$\mathrm{~T}_{8}$ & 17.15 & 18.52 & 211.65 & 12.95 & 14.80 & 127.72 \\
$\mathrm{~T}_{9}$ & 18.84 & 17.09 & 214.60 & 12.97 & 13.90 & 120.15 \\
$\mathrm{SEm}_{ \pm}$ & 0.18 & 0.15 & 0.82 & 0.24 & 0.19 & 0.62 \\
$\mathrm{CD}_{(0.05)}$ & 0.54 & 0.45 & 2.47 & 0.71 & 0.56 & 1.85 \\
\hline
\end{tabular}

$129.84 \mathrm{q} \mathrm{ha}^{-1}$ in Utkal Gaurav were recorded in 2010 (Table 2). The lowest yields (80.00 $\mathrm{q} \mathrm{ha}^{-1}$ and $47.68 \mathrm{q}$ $\mathrm{ha}^{-1}$ ) were recorded in both the varieties in control in the first year of investigation. In 2011, the highest yields (229.62 q ha ${ }^{-1}$ and $131.35 \mathrm{q} \mathrm{ha}^{-1}$ ) were recorded in Mahyco-10 and Utkal Gaurav respectively with integrated application of FYM $\left(10 \mathrm{t} \mathrm{ha}^{-1}\right), 100 \%$ NPK, vermicompost $\left(5 \mathrm{t} \mathrm{ha}^{-1}\right)$ along with biofertilizers $\left(12 \mathrm{~kg} \mathrm{ha}^{-1}\right)$ as presented in Table 3.

There were significant differences observed in the yield due to combined application of organic and inorganic fertilizers as compared to sole application of NPK $(100 \%$ or $75 \%)$ with FYM and in control (FYM @10 t $\mathrm{ha}^{-1}$ ). Dahama [15] reported that the favourable C/N ratio and optimal level of nutrients available for longer period due to slow release might be the possible reasons to influence fruit yield of okra. Edward and Daniel [16] reported that the increase in vegetative growth, yield and yield attributing characters were mainly due to translocation of nutrients and assimilation of photosynthetic activities during the crop growth stage. The activity of Azospirillum in promoting fruit yield was more pronounced, when it was enriched with decomposed organic manures. Similar reports of increased yield in okra were observed due to inoculation with Azospirillum by Parvatham and Vijayan [17] as well as by Subbiah [18].

Inoculation of PSB secretes both organic and inorganic acids such as citric acid, formic acid, acetic acid etc., which solubilize the insoluble form of phosphorus to soluble form and make available to plants [19]. Increased growth and yield in okra due to inoculation of PSB have been reported by Anandan [20] and Prabhu et al. [4]. Combined effects of Azospirillum and PSB in increased yield of okra were reported by Gaur [21] and Poi [22]. Similar findings of increased yield due to combined effects of inorganic fertilizers, biofertilizers with FYM were reported by Patil et al. [23], Prabhu et al. [4] and Shanthi and Vijayakumari [24] in okra. The importance of phosphorus on okra yield was reported by several scientists (Naik and Srinivas, [25] Chattopadhyay and Sahana, [26] El-Shaikh, [27] and Omotoso and Shittu,[28]). Use of biofertilizers can replace the application of $75 \%$ of the recommended dose of nitrogen and phosphorus chemical fertilizers [29,27]. It is evident from the experiment that the enhancement in plant growth attributes by the application of FYM, NPK 100\% plus vermicompost @5 t ha ${ }^{-1}$ and the inoculation with bio-fertilizers reflected on the total pod yield.

\subsection{Economics of Okra Cultivation}

There is a great variation in economics of okra cultivation due to application of different levels of chemical fertilizers and vermicompost along with biofertilizers and FYM was observed and presented in Table 4 (Mahyco-10) and Table 5 (Utkal Gaurav).

\subsubsection{Variety: Mahyco-10}

The total cost of cultivation in okra cv. Mahyco-10 varied between Rs. 46,970 to Rs. $71,360 \mathrm{ha}^{-1}$ under different treatments in 2010 and 2011. Combined use of FYM, 100\% NPK as inorganic fertilizers with vermicompost as organic sources and bio-inoculants in 2010 recorded the highest gross return (Rs. 158,990 ha ${ }^{-1}$ ) while the lowest gross return (Rs. 56,000 ha $\left.{ }^{-1}\right)$ was obtained where only FYM (10 t $\mathrm{ha}^{-1}$ ) was applied. In 2011 the respective gross returns were Rs. 160,730 ha ${ }^{-1}$ and Rs. 56,340 ha ${ }^{-1}$.

The highest net returns (Rs. 87,630 ha ${ }^{-1}$ and Rs. $89,370 \mathrm{ha}^{-1}$ ) was obtained with the conjunctive use of FYM (10 t ha $\left.{ }^{-1}\right)$, inorganic fertilizer (100\% NPK as chemical fertilizers) and organic manure (vermicompost) along with bio-inoculants which was however, comparable with rest of the nutrients. However, the lowest net 
Table 4. Economics of okra cultivation (Variety: Mahyco-10) as influenced by diazotrophs and chemical fertilizers.

\begin{tabular}{|c|c|c|c|c|c|c|c|c|c|c|c|c|}
\hline \multirow[t]{2}{*}{ Treatments } & \multicolumn{3}{|c|}{$\begin{array}{l}\text { Total Expenditure } \\
\text { (000` Rs/ha) }\end{array}$} & \multicolumn{3}{|c|}{$\begin{array}{l}\text { Gross Return } \\
\text { (000`Rs/ha) }\end{array}$} & \multicolumn{3}{|c|}{$\begin{array}{l}\text { Net Return } \\
\left(000^{`} \text { Rs/ha) }\right.\end{array}$} & \multicolumn{3}{|c|}{ Benefit Cost Ratio } \\
\hline & 2010 & 2011 & Mean & 2010 & 2011 & Mean & 2010 & 2011 & Mean & 2010 & 2011 & Mean \\
\hline $\mathrm{T}_{1}$ & 46.97 & 46.97 & 46.97 & 56.00 & 56.34 & 56.17 & 9.03 & 9.37 & 9.20 & 1.19 & 1.20 & 1.20 \\
\hline $\mathrm{T}_{2}$ & 56.15 & 56.15 & 56.15 & 119.96 & 122.18 & 121.07 & 63.81 & 66.03 & 64.92 & 2.14 & 2.18 & 2.16 \\
\hline $\mathrm{T}_{3}$ & 56.15 & 56.15 & 56.15 & 116.90 & 119.20 & 118.05 & 60.75 & 63.05 & 61.90 & 2.08 & 2.12 & 2.10 \\
\hline $\mathrm{T}_{4}$ & 56.36 & 56.36 & 56.36 & 127.44 & 129.57 & 128.51 & 71.08 & 73.21 & 72.15 & 2.26 & 2.30 & 2.28 \\
\hline $\mathrm{T}_{5}$ & 56.36 & 56.36 & 56.36 & 125.04 & 126.54 & 125.79 & 68.68 & 70.18 & 69.43 & 2.22 & 2.25 & 2.23 \\
\hline $\mathrm{T}_{6}$ & 71.36 & 71.36 & 71.36 & 158.99 & 160.73 & 159.86 & 87.63 & 89.37 & 88.50 & 2.23 & 2.25 & 2.24 \\
\hline $\mathrm{T}_{7}$ & 63.86 & 63.86 & 63.86 & 141.23 & 143.92 & 142.57 & 77.37 & 80.06 & 78.71 & 2.21 & 2.25 & 2.23 \\
\hline $\mathrm{T}_{8}$ & 63.86 & 63.86 & 63.86 & 147.59 & 148.16 & 147.87 & 83.73 & 84.30 & 84.01 & 2.31 & 2.32 & 2.32 \\
\hline $\mathrm{T}_{9}$ & 71.36 & 71.36 & 71.36 & 148.97 & 150.22 & 149.60 & 77.61 & 78.86 & 78.24 & 2.09 & 2.11 & 2.10 \\
\hline
\end{tabular}

Table 5. Economics of okra cultivation (Variety: Utkal Gaurav) as influenced by diazotrophs and chemical fertilizers.

\begin{tabular}{|c|c|c|c|c|c|c|c|c|c|c|c|c|}
\hline \multirow[t]{2}{*}{ Treatments } & \multicolumn{3}{|c|}{$\begin{array}{l}\text { Total Expenditure } \\
\left(000^{`} \mathrm{Rs} / \mathrm{ha}\right)\end{array}$} & \multicolumn{3}{|c|}{$\begin{array}{c}\text { Gross Return } \\
\text { (000` Rs/ha) }\end{array}$} & \multicolumn{3}{|c|}{$\begin{array}{c}\text { Net Return } \\
\text { (000`Rs/ha) }\end{array}$} & \multicolumn{3}{|c|}{ Benefit Cost Ratio } \\
\hline & 2010 & 2011 & Mean & 2010 & 2011 & Mean & 2010 & 2011 & Mean & 2010 & 2011 & Mean \\
\hline $\mathrm{T}_{1}$ & 23.95 & 23.95 & 23.95 & 28.61 & 28.36 & 28.49 & 4.66 & 4.41 & 4.54 & 1.19 & 1.18 & 1.19 \\
\hline $\mathrm{T}_{2}$ & 48.34 & 48.34 & 48.34 & 54.92 & 55.53 & 55.22 & 6.58 & 7.19 & 6.88 & 1.14 & 1.15 & 1.14 \\
\hline $\mathrm{T}_{3}$ & 48.34 & 48.34 & 48.34 & 54.14 & 54.26 & 54.20 & 5.80 & 5.92 & 5.86 & 1.12 & 1.12 & 1.12 \\
\hline $\mathrm{T}_{4}$ & 48.55 & 48.55 & 48.55 & 55.22 & 56.67 & 55.94 & 6.67 & 8.12 & 7.39 & 1.14 & 1.17 & 1.15 \\
\hline $\mathrm{T}_{5}$ & 48.55 & 48.55 & 48.55 & 54.93 & 56.14 & 55.53 & 6.38 & 7.59 & 6.98 & 1.13 & 1.16 & 1.14 \\
\hline $\mathrm{T}_{6}$ & 63.55 & 63.55 & 63.55 & 77.90 & 78.81 & 78.36 & 14.35 & 15.26 & 14.81 & 1.23 & 1.24 & 1.23 \\
\hline $\mathrm{T}_{7}$ & 56.05 & 56.05 & 56.05 & 63.12 & 65.29 & 64.20 & 7.07 & 9.24 & 8.15 & 1.13 & 1.16 & 1.15 \\
\hline $\mathrm{T}_{8}$ & 56.05 & 56.05 & 56.05 & 66.39 & 67.63 & 67.01 & 10.34 & 11.58 & 10.96 & 1.18 & 1.21 & 1.20 \\
\hline $\mathrm{T}_{9}$ & 62.00 & 62.00 & 62.00 & 71.36 & 72.09 & 71.73 & 9.36 & 10.09 & 9.73 & 1.15 & 1.16 & 1.16 \\
\hline
\end{tabular}

returns of Rs. 9370 ha $^{-1}$ and Rs. 9200 ha $^{-1}$ were obtained in 2010 and 2011 respectively when only FYM@10 t $\mathrm{ha}^{-1}$ (control) were applied. Maximum benefit cost ratio (2.31 and 2.32) was obtained by combined application of FYM (10 t ha ${ }^{-1}$ ), 100\% NPK with vermicompost @2.5 t ha $^{-1}$ along with biofertilizers in 2010 and 2011 respectively.

\subsubsection{Variety: Utkal Gaurav}

The maximum cost of cultivation (Rs 63,550 ha ${ }^{-1}$ ) was observed in $\mathrm{V}_{2} \mathrm{~T}_{6}$. The maximum cost was incurred when FYM(10 $\left.\mathrm{t} \mathrm{ha}^{-1}\right), 100 \%$ recommended dose of chemical fertilizers, vermicompost @5 t ha ${ }^{-1}$ along with biofertilizers and FYM were applied. However, the least cost (Rs 23,950) was incurred where only FYM@10 t ha ${ }^{-1}$ was applied. Combined use of FYM, $100 \%$ NPK of as inorganic fertilizers with vermicompost as organic sources and bio-inoculants recorded the highest gross return (Rs 77,900 ha ${ }^{-1}$ and Rs 78,810 ha- ) while the lowest gross return (Rs 28,610 ha ${ }^{-1}$ and Rs 28,360 ha ${ }^{-1}$ ) was obtained in control where only FYM @ $10 \mathrm{t} \mathrm{ha}^{-1}$ was applied.

The highest net return (Rs 14,350 ha ${ }^{-1}$ and Rs 15,260 ha $^{-1}$ ) was obtained in $\mathrm{V}_{2} \mathrm{~T}_{6}$ with conjunctive use of
FYM, inorganic fertilizer (100\% NPK as chemical fertilizers) and organic manure (vermicompost) along with bio-inoculants. This is significantly superior to the net return (Rs $7190 \mathrm{ha}^{-1}$ and Rs $6880 \mathrm{ha}^{-1}$ ) obtained with the sole application of $100 \%$ RDF with FYM. The lowest net returns of Rs $4410 \mathrm{ha}^{-1}$ and Rs $4540 \mathrm{ha}^{-1}$ were obtained in 2010 and 2011 respectively in control. The maximum benefit cost ratio (1.23 and 1.24) was noticed in 2010 and 2011 respectively by applying FYM, 100\% NPK as chemical fertilizers along with vermicompost @5 $\mathrm{t} \mathrm{ha}{ }^{-1}$ and biofertilizers followed by $\mathrm{V}_{2} \mathrm{~T}_{8}(1.18$ and 1.21). The lowest benefit cost ratio (1.12) was in $\mathrm{V}_{2} \mathrm{~T}_{3}$. The benefit cost ratio indicate that the crop receiving the highest fertilizer doses which includes vermicompost and biofertilizers is the best nutrient management practices where the farmers/growers can earn Rs 1.23 and Rs 1.24 per rupee of investment followed by other treatments tried in this experiment in both the years.

There is a variation in cost of cultivation among treatments and variety due to application of varying rate of fertilizers and manures and the variation in seed cost of hybrid and open pollinated high yielding varieties. The higher gross return is 
owing to higher total green fruit yield. The higher net returns and benefit cost ratio of hybrids clearly indicate the better economic viability of hybrids over open pollinated varieties under similar agro climatic conditions. With regard to impact of INM practices on economic feasibility, the present findings indicate significantly higher gross returns in okra variety Mahyco-10 (Rs 158,990 and Rs 160,730 ha ${ }^{-1}$ ) among all the integrated treatments as compared to control and the sole application of chemical fertilizers with FYM.Similarly in Utkal Gaurav variety the highest gross return (Rs 77,900 ha ${ }^{-1}$ and Rs 78,810 $\mathrm{ha}^{-1}$ ) was obtained with higher nutrient management.

Application of FYM, 100\% RDF with vermicompost along with inoculation of bio-fertilizer recorded significantly higher yield which is responsible for higher economic return. With respect to B:C ratio, in Mahyco-10 the studies revealed significantly higher values by application of higher dose of fertilizers as compared to the other treatments evaluated. This is obviously due to significantly higher total fruit yield with higher levels of organic manures. Similar results of higher benefit cost ratio by adoption of INM practices were also observed by Patil et al. [30] in okra.

\section{Conclusion}

In the changing scenario, an increasing number of farmers or vegetable growers are switching over to cultivation of hybrids in India. These hybrid varieties need relatively higher quantum of plant nutrients for exhibiting their genetic potential for producing more yields. Investigations carried out for two years on the integrated use of fertilizers on okra have revealed that the cultivar "Mahyco-10 and Utkal Gaurav" could be profitably grown under Bhubaneswar agro-climatic condition with the application of $100 \%$ of recommended dose of NPK i.e., 200:100:100 kg ha ${ }^{-1}$ for Mahyco-10 and 110:75:75 kg $\mathrm{ha}^{-1}$ for Utkal Gaurav along with vermicompost $\left(5 \mathrm{t} \mathrm{ha}^{-1}\right)$, biofertilizers (12 kg ha $\left.{ }^{-1}\right)$ and FYM $\left(10 \mathrm{t} \mathrm{ha}^{-1}\right)$. It can be concluded that the combined application of bio-inoculants with organic manures and inorganic fertilizers enhanced the yield and yield attributing characters and received higher net return as compared to the sole application of inorganic fertilizers (100\% RDF or 75\% RDF) and control (FYM@10 t ha ${ }^{-1}$ ) as well.

\section{REFERENCES}

[1] H. D. Tindal, "Vegetables in the Tropics," Mac-Millan Education Limited, Houndmills, 1983, 533 p.

[2] Report of National Horticulture Board, 2010-2011.

[3] K. P. Singh and G. Kalloo, "Nutrient Management in Vegetable Crops,” Fertilizer News, Vol. 45, No. 4, 2000, pp. 77-81.
[4] T. Prabhu, P. R. Narwadekar, A. K. Sannindranath and M. Rofi, "Effect of Integrated Nutrient Management on Growth and Yield of Okra (Abelmoschus esculentus (L.) Moench) cv. Parbhani Kranti," The Orissa Journal of Horticulture, Vol. 31, No. 1, 2003, pp. 17-21.

[5] G. Neeraja, B. Gautham and I. P. Reddy, "Comparative Yield Trial in Okra (Abelmoschus esculentus L) Hybrids under Southern Telangana Zone of Andhra Pradesh,” The Orissa Journal of Horticulture, Vol. 30, No. 2, 2002, pp. 20-22.

[6] C. A. Fatokun and H. R. Chheda, "The Effects of Nitrogen and Phosphorus on Yield and Chemical Composition of Okra (Abelmoschus esculentus L. Moench) ISHS," Acta Horticulturae, Vi African Symposium on Horticultural Crops, 1980.

[7] U. C. Pandey, S. Lal, M. L. Pandita and G. Singh, "Effect of Nitrogen and Phosphorus Levels of Seed Production of Okra (Abelmoschus esculentus (L.) Moench)," Haryana Journal of Horticultural Sciences, Vol. 9, 1980, pp. 165169.

[8] L. B. Naik and K. Srinivas, "Influence of N and P Fertilization on Seed Crop of Okra,” Indian Journal of Agronomy, Vol. 37, 1992, pp. 769-771.

[9] N. Ahmed and M. I. Tanki, "Effect of Nitrogen and Phosphorus on Growth and Seed Yield of Okra," Indian Journal of Horticulture, Vol. 54, No. 2, 1997, pp. 156159.

[10] B. K. Senapati, M. C. Dash, A. K. Rana and B. K. Panda, "Observation on the Effect of Earthworm in the Decomposition Process in Soil under Laboratory Conditions," Comparative Physiology and Ecology, Vol. 5, 1980, pp. 140-142.

[11] K. Bano, R. D. Kale and G. S. Gajanan, "Culturing of Earthworms (Eudrillus eugeniae) for Casts Production,” Proceedings of the National Symposium on Soil Pest and Soil Organism, Banaras, 1984.

[12] R. P. Kuwar, K. J. Kubde, S. D. Malvi, S. T. Dangare and P. D. Raut, "Response of Okra Genotypes to Varying Plant Density,” PKV Research Journal, Vol. 25, No. 1, 2001.

[13] B. K. Birbal and Y. S. Nehara Malik, "Effect of Spacing and Nitrogen on Fruit Yield of Okra (Abelmoschus esculentus L. Moench),” Haryana Agricultural University Journal of Research, Vol. 25, 1995, pp. 47-51.

[14] R. P. Singh, C. B. S. Rajput and S. N. S. Chaurasia, "Effect of Different Levels and Methods of Potassium Application on Growth and Green Pod Yield of Okra (Abelmoschus esculentus (L) Moench) cv. Parbhani Kranti,” Haryana Journal of Horticultural Sciences, Vol. 27, No. 4, 1998, pp. 288-292.

[15] A. K. Dahama, "Organic Farming for Sustainable Agriculture,” Agrobios (India), Jodhpur, 2003.

[16] Edward and Daniel, "Effects on Earthworms on Soil Physical Properties and Function,” In: C. A. Edwards, Ed., Earthworm Ecology, St. Lucie Press, London, 1992, pp. 147-162.

[17] A. Parvatham and K. P. Vijayan, "Effect of Azospirillum 
Inoculation on Yield and Yield Components and Quality of Bhendi Fruits,” South Indian Hort., Vol. 37, 1989, pp. 350-352.

[18] K. Subbiah, "Studies on the Effect of Nitrogen and Azospirillum on Okra," South Indian Hort., Vol. 39, No. 1, 1991, pp. 37-44.

[19] S. S. Bora, A. P. Singh and N. Kumar, "Biofertilizers: Natural Cheap Source of Nutrients,” Farmers Digest, Vol. 35, 2002, pp. 11-12.

[20] M. Anandan, "Integrated Approach of Bio-Fertilizer for Sustainable Agriculture,” Intensive Agriculture, Vol. 38, No. 1-2, 2000, pp. 9-11.

[21] A. C. Gaur, "Phosphate Solubilizing Microorganism as Biofertilizers,” Omega Scientific Publishers, New Delhi, 1990.

[22] S. C. Poi, "Effect of Azospirillum lipoferum and Pseudomonas striata as Inoculants on Some Vegetable Crops for Nitrogen and Phosphate Nutrition Soils of West Bengal," Ecology and Environment, Vol. 16, No. 2, 1998, pp. 388389.

[23] M. B. Patil, S. D. Jogdand and A. S. Jadhar, "Effect of Organic and Bio-Fertilizers on Yield and Quality of Okra," Journal of Maharashtra Agricultural Universities, Vol. 25, No. 2, 2000, pp. 213-214.

[24] N. Shanthi and B. Vijayakumari, "Effect of NPK with Different Organic Manures on Biometric Parameters of Bhendi (Abelmoschus esculentus L. var. Arka Anamika)," Journal of Phytological Research, Vol. 15, No. 2, 2002, pp. 209-212.

[25] L. B. Naik and K. Srinivas, "Influence of Nitrogen and Phosphorus Fertilization on Seed Crop of Okra (Abelmoschus esculentus)," Indian Journal of Agronomy, Vol. 37, No. 4, 1994, pp. 769-771.

[26] A. Chattopadhyay and B. C. Sahana, "Response of Okra Seed Crop to Nitrogen and Phosphorus Fertilization in Acidic Soil of Old Alluvial Zone, West Bengal,” Research on Crops, Vol. 1, No. 2, 2001, pp. 176-180.

[27] K. A. A. El-Shaikh, "Effect of Phosphorus and Potassium Fertilization on Green Yield, Seed Production and Quality of Two Okra Cultivars in Reclaimed Soils," Assiut Journal of Agricultural Science, Vol. 36, No. 1, 2005, pp. 51-68.

[28] S. O. Omotoso and O. S. Shittu, "Effect of NPK Fertilizer Rates and Method of Application on Growth and Yield of Okra (Abelmoschus esculentus L. Moench.)," Research Journal of Agronomy, Vol. 1, No. 2, 2007, pp. 84-87.

[29] G. Charron, V. Furlan., M. Bernier-Cardou and G. Doyon, "Response of Onion Plants to Arbuscular Mycorrhizae. I-Effect of Inoculation Method and Phosphorus Fertilization on Biomass and Bulb Firmness,” Mycorrhizae, Vol. 11, No. 4, 2001, pp. 187-197.

[30] M. P. Patil, N. C. Hulamani, S. I. Athani and M. P. Patil, "Response of New Tomato Genotype Megha to Integrated Nutrient Management," Advances in Agricultural Research in India, Vol. 9, 1998, pp. 39-42. 